\title{
Austrian foreign policy and 20 years of EU membership: Opportunities and constraints
}

\author{
Patrick Müller ${ }^{1, *}$, Heidi Maurer ${ }^{2, *}$ \\ 1 Faculty of Social Sciences, University of the Basque Country (UPV/EHU)/ Leioa Campus, Bilbao, Spain. \\ 2 Faculty of Arts and Social Sciences, Maastricht University, Maastricht, The Netherlands. \\ * E-Mail: patrick.muller@ehu.eus, h.maurer@maastrichtuniversity.nl
}

\begin{abstract}
When Austria joined the EU in 1995 it had to find its place in a substantially altered world order. Yet, rather than conceiving its membership in the EU as an opportunity to reenergize its foreign policy through Europeanization, Austria has displayed little interest in developing an active foreign policy profile within, or through, the EU. While membership in the EU meant a broadening of Austria's foreign policy agenda - as Austria became involved in a broad range of international issues and started to participate in the multi-level negotiation process of the EU - its main contributions to European foreign policy occurred in areas close to its national interest, as exemplified by its active role in the Western Balkans. Simultaneously, EU membership placed considerable constraints on Austria's formerly independent national foreign policy, especially on Austria's neutrality. This special issue brings together different international scholars with a longstanding expertise on different aspects of Austrian foreign policy that they will cover to take stock of the Europeanization of Austrian foreign policy two decades after it joined the EU.
\end{abstract}

\section{Keywords}

Austria; foreign policy; EU membership; Europeanisation

\section{Österreichis Außenpolitik und 20 Jahre EU-Mitgliedschaft: Möglichkeiten und Beschränkungen}

\section{Zusammenfassung}

Zum Zeitpunkt seines EU Beitritts 1995 musste Österreich seine außenpolitische Rolle in einer neuen Weltordnung neu definieren. Die Mitgliedschaft in der EU wurde dabei allerdings nicht systematisch genutzt, um durch eine Europäisierung nationaler Außenpolitik an globalem Einfluss und Gestaltungsmöglichkeiten zu gewinnen. Österreich hat insgesamt eher wenig Interesse gezeigt, eine aktive Rolle innerhalb der europäischen Außenpolitik zu entwickeln. Während die EU Mitgliedschaft eine signifikante Ausweitung der außenpolitischen Agenda bedeutet und Österreich sich in die Prozesse europäischer Politikgestaltung integriert hat, blieb der Schwerpunkt der österreichischen Diplomatie weitgehend auf nationale außenpolitische Interessen fokussiert. Dies zeigt sich etwa an der aktiven Rolle Österreichs im Rahmen der europäischen Politik gegenüber dem Westbalkan. Gleichzeitig kam es im Zuge der EU Mitgliedschaft zu Beschränkungen der einst unabhängigen österreichischen Außenpolitik, gerade etwa in Bezug auf Österreichs Neutralität. Dieses Schwerpunkheft vereinigt internationale Experten, um 20 Jahre nach dem EU Beitritt bilanzieren über den Stand der Europäisierung verschiedener Aspekte österreichischer Außenpolitik. Insbesondere thematisieren die einzelnen Beiträge die Bereiche Kooperation in der Außen- und Sicherheitspolitik, Entwicklungspolitik, sowie die Veränderungen diplomatischer Praktiken und Institutionen.

\section{Schlüsselwörter}

Österreich; Außenpolitik; EU Mitgliedschaft; Europäisierung

The authors have declared that no competing interests exist. 


\section{Introduction}

In 20I5, Austria has been a member of the EU for 20 years. With Austria joining the European Union (EU) in 1995, its foreign policy became closely intertwined with the EU's collective foreign policy, which itself has evolved considerably since Austria had become a member. This special issue is interested in the role EU-membership has played in Austria's foreign policy response to an altered international environment, characterized by the proliferation of new security threats, significant changes in Europe's neighborhood (Müller 20I6), and more recently a global financial crisis and austerity measures that further limit the resource base for national foreign policy. How has Austrian foreign policy adapted to these changing conditions (adjustment through as well as adjustment because of the EU)? And did the EU function as an opportunity or as a constraint for national foreign policy reforms? At the same time, we are interested in the way Austria, as a small member state, relates to EU foreign policy-making and in its capacity to contribute to EU foreign policy. Hence, this special issue covers different analytical and empirical aspects concerning the 'EUdimension' of Austrian foreign policy.

Whilst the Europeanization of EU member state foreign policy has received considerable attention over the last decade, including an insightful study on the Europeanization of Austrian foreign policy (Alecu de Flers 20I2), this special issue will innovate both at the theoretical and empirical levels. Conceptually, we combine insights from small state theory (see e.g. Höll/Gärtner 200I) with the Europeanization framework to identify important ways in which countries like Austria can compensate for their more limited resources so as to play an active role in European foreign policy cooperation, relying on strategies like specialization, the strategic use of EU resources, and forging alliances (see also Panke 20IO; Rose/Trechsel 20I3). This 'bottom-up' influence of small states in EU foreign policy - which are often considered to be 'takers' rather than 'shapers' of EU foreign policy - has thus far received relatively sparse attention.

This special issue addresses this research gap, bringing together scholars from different countries and academic institutions with a strong and longstanding expertise on different aspects of Austrian foreign policy - change to: including security cooperation, development cooperation and diplomacy - that they will cover in their individual contributions. Furthermore, we pay attention to additional, innovative mechanisms of 'top-down Europeanization', including pressures resulting from restrictions of foreign policy resources through events like the financial crisis and to shifting national priorities. Finally, our conceptual framework is especially sensitive to the circumstance that Austrian foreign policy is not only responding to the European foreign policy environment, but also to a changing global context.
Empirically, we do not limit our analysis to the field of foreign and security policy, as much of the Europeanization literature does, but include development policy as an additional field. Additionally, the special issue looks at changes of Austrian diplomacy in the context of the revamped, post-Lisbon European foreign policy system. It, moreover, covers Austria's participation in regional schemes - i.e. the Salzburg Forum and Central European Defense Cooperation (CEDC) - in internal and external security, and Austrian diplomacy. While there is no shortage of perceptive analysis of different aspects of Austrian foreign policy by leading experts in the field (see e.g. Kramer 20I3; Pucher/Frank 20I2; Gärtner 2OII) we explore different aspects of Austrian foreign policy through a single analytical framework, allowing for more systematic comparison. Kramer's contributions stands out here, as it is particularly concerned with the domestic foundations and drivers of Austrian foreign policy, which is useful to put Europeanization effects in perspective.

Europeanization is a process that unfolds through time. Our contributions take a historical perspective to study how Austria has influenced EU foreign policy and how its foreign policy has been shaped by EU membership since it joined in I995. At the same time, more recent events - like the Lisbon Treaty or the financial crisis and ensuing austerity - deserve particular attention. At the time of writing, the 'migrant crisis' has developed into another major challenge for the EU that has also important foreign policy implications; and just a few days prior to submission of this special issue the British referendum to leave the EU has placed considerable uncertainty on the future of EU foreign policy. While these events are of historic magnitude and clearly deserve scholarly attention, given the timing of this special issue they will need to be addressed systematically by future research. This introduction outlines in a next step the main conceptual underpinnings of the special issue, after which we briefly discuss the main results of the individual contributions and the conclusion that Austria acts mostly as pragmatic bystander in EU foreign policymaking.

\section{Small member states and the Europeaniza- tion of foreign policy}

Research applying the Europeanization framework to the foreign policy domain has predominantly focused on the bi-directorial relations between the EU Foreign Policy, the upper governance layer, and the national foreign policies of individual member states, representing the lower governance layer. Member states 
can seek to influence EU foreign policy in a bottom-up direction, projecting national interests and priorities to the EU level (policy uploading). The EU's Common Foreign and Security Policy (CFSP) provides member states with an instrument to achieve objectives that are difficult to obtain through national action. Here, the pooling of resources results in a 'politics of scale effect' (Ginsberg 1989), which increases the influence of EU member states' governments in world affairs and provides an incentive for member states to proactively project their preferences onto the EU level in a bottom-up direction.

As stated above, while European foreign policymaking is often portrayed as a game of the EU's major powers, it would be misleading to look at small EU member states as passive receivers of EU decisions. Small states are limited in resources and expertise, yet the EU treaties grant an equal legal status to all member states. And by imposing 'obligations of membership on big as well as small states, the latter enjoy protection that they would be unable to achieve on their own' (Rose/Trechsel 2013, 4). What is more, the literature on small states points to a number of strategies through which small member states can compensate for disadvantages in terms of size and policy options (see also Panke 20I0). On the other hand, however, membership in the CFSP can be expected to also have a considerable impact on the foreign policy of Austria.

\subsection{The bottom-up perspective: Europeanization as policy uploading}

Drawing on research on small state foreign policy can enrich our understanding of bottom-up Europeanization, pointing to ways in which small states may compensate for limitations in terms of (financial) resources, staff, expertise and political clout. Specifically, small, or medium sized states like Austria can employ the following strategies to influence policy outcomes at the EU level.

- Forging alliances: to enhance its influence in EU foreign policymaking Austria may forge strategic partnerships/alliances with other member states/EU actors;

- Prioritization of objectives and resources: Austria may concentrate its resources and expertise on particular geographical areas or specific thematic issues covered at the EU-level to compensate for its limited resources, enhancing its capacity, expertise and building a strong reputation to make an impact on particular issues;

- Drawing on EU resources: Austria may actively use/ draw on EU resources (e.g. of the Commission, or the EEAS) to enhance its influence.
Member states may differ according to the level of activeness to which they pursue policy up-loading, i.e. the time, effort and resources they invest in influencing and contributing to joint European foreign policy outputs (e.g. EU declarations, positions, or operation action). At the same time, member states may differ in terms of the substantive impact of foreign policy uploading. The substantive impact of foreign policy uploading can be assessed in terms of the degree to which a member states' national foreign policy priorities and positions are reflected in collective European foreign policy output.

\subsection{The top-down perspective: Europeanization as policy-downloading}

Conversely, scholars pointed a number of ways in which EU foreign policy can impact on the national foreign policies of individual member states in a top-down direction. The top-down dimension of Europeanization relates to the impact of EU structures, processes and policies on Austrian national foreign policy. It is commonly understood that top-down Europeanization dynamics differ between more supranationalized policy fields such as Justice and Home Affairs (JHA) - which involves the adoption of EU law that is binding on the member states - and intergovernmental fields like the EU's Common Foreign and Security Policy (CFSP) and its defence component, the Common Security and Defence Policy (CSDP) (see e.g. Featherstone/Radaelli 2003: 152). Concerning the latter, top-down Europeanization involves voluntary dynamics such as reflexes for coordination and information sharing, elite socialisation, and reputation building through which participation in CFSP impacts on the member states national foreign policies (see Smith 2004). ${ }^{1}$

Top-down Europeanization may involve change in terms of a member states' foreign policy structures (i.e. organizational structures, routines, procedures of foreign policy) or in terms of foreign policy substance (i.e. foreign policy priorities, objectives, and behavior). Specifically, we will rely on the following indicators to examine top-down Europeanization (see also Wong 2005; Müller 2012):

- Re-organization of Foreign Policy structures, procedures, and routines to adopt national foreign policy apparatus to working mode of EU.

- Increasing salience of European political agenda: growing adherence to common objectives; adjustment of national foreign policy to EU positions, priorities and acquis.

I All major decisions in CFSP require consensus among the member states in the Council, whilst the European Commission only plays a supportive role and other supranational actors like the European Parliament and the European Court of Justice enjoy only limited influence. 
- Growing contribution to EU policies: greater willingness to work through the EU framework and/or enhanced contribution to an EU policy (financially, operationally etc.).

\subsection{The horizontal perspective: Europeanization as cross-loading}

Besides this vertical understanding of Europeanization as policy 'uploading' and 'downloading', scholars have also pointed to horizontal Europeanization dynamics that involve the 'cross-loading' of ideas, norms and ways of doing things between individual member states' (Major 2005, I68; see also Wong 2005). Studies on the horizontal pathway of Europeanization are few, however, which stands in contrast to the proliferation of Europeanization studies that explore the bi-directional, vertical interaction between the national and EU-levels. ${ }^{2}$ The impact of cross-loading is not primarily directed towards joint foreign policy outputs, though it can have a cumulative impact on EU foreign policy. Rather, crossloading is concerned with the influence individual member states, or sub-groups of member states, have on each other. Accordingly, it can be assumed that the increasing extend to which sub-groups of EU member states cooperate with each other within the treaty structure of the EU - as captured in concepts such as 'flexible integration', 'differentiated integration', or 'Europe al la carte' (see Holzinger/Schimmelfennig 20I2) - will increase the relevance of 'cross-loading'.

Besides cooperation within the formal structures of the EU, bi- and multilateral groupings involving sub-sets of EU member states - and sometimes also including non-EU countries - have emerged often organizing on a geographical basis (see Müller in this volume). Among other things, this includes the Salzburg Forum, the Benelux countries, the Baltic Seas Task Force (the three Baltic states and Denmark, Finland, Germany, Iceland, Norway, Poland, Sweden, and Russia), the 'Visegrad group'

Figure 1: Pathways of Europeanization

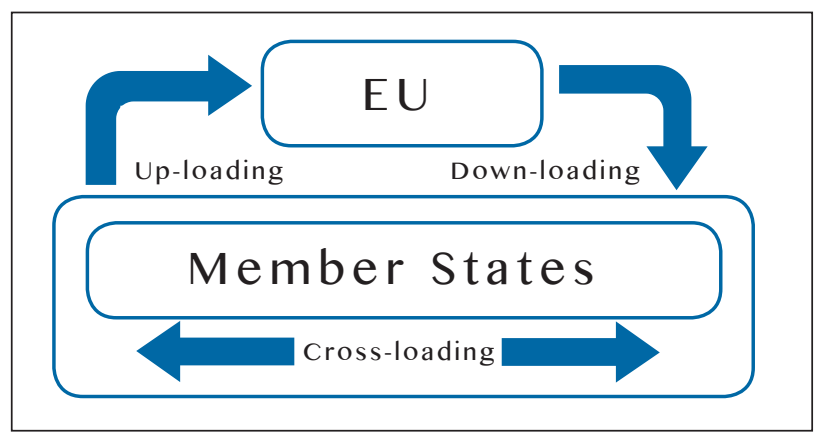

2 As Tonra (2015) points out, notable exceptions include works on the European Neighbourhood Policy (Normann 2012) and of Finnish foreign policy (Palosaari 20II). (the Czech Republic, Hungary, Poland, and Slovakia), as well as the so called 'G-6' group (France, Germany, Italy, Spain and the United Kingdom and Poland). While the prevalence of multilateral cooperation among sub-sets of EU member states is generally acknowledged in the relevant literature, its impact on Europeanization dynamics largely remains a research desideratum. The different pathways on Europeanization (up-loading, downloading, cross-loading) are displayed in figure I below.

\subsection{Austria and domestic drivers of foreign policy}

It is important to bear in mind, however, that Austrian foreign policy does not simply develop in response to (systemic) changes in its international environment, including EU related developments, but is also shaped by domestic foreign politics (see e.g. Fearon I998). ${ }^{3}$ This insight is reminiscent of the broader debate between domestic and 'systemic' accounts of international relations (IR). IR research has not only identified important domestic drivers of foreign policy, like political institutions, economic structures and leadership goals, but has moved beyond the futile question of whether domestic or international factors matter for foreign policy. Today, most scholars would agree with Putnam (1988) that both factors matter at times and that the more interesting questions are 'when' and 'how' these factors matter. As Hagan (I993: 4) reminded us, in Western democracies the central link between domestic politics and foreign policy systems stems principally from the domestic imperative of retaining political power, which makes policymakers sensitive to domestic demands and opportunities.

Domestic processes are frequently understood to be an important part of the formation of state preferences and national interests, especially by scholars working in the liberal tradition (see esp. Moravcsik 1997). However, mixing narrowly defined domestic objectives with foreign policy can also undermine genuine foreign policy objectives (Smith 1996). Miller points out that diplomats, foreign-policy analysts and academics are generally hostile towards mixing domestic politics with foreign policy, as '(t)he first is seen as hot, sordid, and more often than not, unworthy' whilst ' $(\mathrm{t})$ he second is thought to be cool, principled, logical - an endeavour of the highest order' and results for the activities of 'skilled practitioners and dedicated professionals' (Miller 20I3). Realizing domestic gains through foreign policy activities might be tempting for politicians seeking re-election,

3 As it has previously been acknowledged, Europeanization research involves the methodological challenge of dealing with 'equifinality' - that is, scholars must differentiate between changes resulting from Europeanization and changes caused by other phenomena in both the international and domestic spheres of EU Member States (see Alecu de Flers/Müller 20IO). 
but it might not be in the best interest of a state's (long term) foreign policy interests.

To be sensitive to 'domestic' dynamics in Austrian foreign policy, this special issue includes a contribution by Kramer that is providing an insightful historical account of key domestic developments that underpin Austrian foreign policy. While these domestic explanations of Austria's national foreign policy remain outside the theoretical perspective of the Europeanization framework as such, they still allow to put the observed developments into perspective and facilitate a better understanding of domestic sources of Austria's policy within the EU. In particular, Kramer's contribution shows that domestic politics have turned into a defining feature and in fact crucial limitation - of Austrian foreign policy, making it difficult for Austrian foreign policymakers to develop a more ambitious profile in EU foreign policy (see also the findings below).

\section{Comparative findings: Austria as a pragmatic bystander in EU foreign policy}

While twenty years of EU membership clearly have left their mark on Austrian foreign policy, it is interesting to note that Austria has made no real systematic effort to develop an active role in EU foreign policy, as the main findings of this special issue contributions show. Having gained much international credibility for its 'active neutrality' policy during the Cold War era, Austria till today lacks a comparable strategic vision for a similarly active role in the EU. By and large, it appears that there is a lack of imagination and ambition when it comes to defining Austria's place in EU foreign policy. Though Austria is generally supportive of the EU's foreign policy at the rhetorical level, it has not contributed much to it in actual practice and has remained somewhat aloof in EU foreign policymaking. On the basis of the findings of this special issue, Austria's role might be best characterized as that of a 'pragmatic bystander', or a 'fence sitter', who keeps its input in terms of ideas, policy initiatives, and resources minimal and does not become involved much beyond taking care of its immediate concerns. Austria's involvement remains pragmatic, ad hoc and limited to narrowly define national objectives and impulses, rather than being re-oriented towards collective vision for Europe and the 'common good'. As Kramer aptly notes, the EU has gradually been transformed into a political Union where the pursuit of national interests has to be combined with an obligation of acting in the spirit of a mutual supportive community ('Solidargemeinschaft'). Austria's pragmatist foreign policy fails to appreciate this spirit of political Community and has even been described as an attempt to 'keep outside' of EU politics (Kramer in this special issue). As another observer has put it, Austria "has its back to Brussels and looks towards Eastern and Southeastern Europe, where it earns most of its money' (De Gruyter 20I4).

Uploading of foreign policy to the EU level: Austria has kept its active contribution to EU foreign policy largely limited to promoting narrowly defined national interests and to ad hoc interventions to make gains in domestic politics. In line with Austria's past mediation role as neutral country, Austrian diplomats in the EU have traditionally revealed a tendency to avoid conflict, to embrace the 'middle position' in negotiations, and to respond to policy initiatives of other actors rather than to drive foreign policy. Following the 1999 EU sanctions against Austria's coalition government that included the right wing freedom party (FPÖ), Austrian diplomats became more accustomed to explain and defend Austrian positions in the EU (see Maurer in this special issue), particularly in areas that relate to Austrian concerns like the Western Balkans. This evolving activism on the ground by diplomats, however, only rarely finds its way back in the mindset of decision-makers in Vienna.

Limiting its agenda to key priorities has hence been a clear strategy for Austria in EU foreign policymaking. As part of its pragmatic attitude towards European foreign policy cooperation, Austria tends to direct its activism towards national priorities and objectives, rather than to contribute to the visibility, strength and success of the EU's common foreign policy. Overall, Austria does not invest much resources in its diplomatic capacity and foreign policy capabilities, nor does it invest much in EU foreign policy. As the contributions by Maurer and Kramer to this special issue show, Austrian diplomacy has been challenged by continued financial cuts and is chronically understaffed. Austria also maintains far less diplomats dealing with foreign policy issues in Brussels than states with a comparative size and economic strength, such as Sweden. Similarly, Lightfoot and Obrovsky point out that Austria's financial commitment to (EU) development policy does not correspond to it privileged economic status. Austria spends less on development assistance than similarly prosperous EU countries (e.g. Ireland, Sweden, Belgium, and Denmark), undermining its profile among donors.

Limited foreign policy resources thus challenge Austria's role in EU foreign policy, making it all the more important for Austria to rely on 'compensation strategies'. Prioritization has been one way of Austria to deal with resource limitations. Geographically, Austria has given strong priority to the EU's foreign policy towards Central and Eastern Europe - firmly supporting the EU's Eastern enlargement - as well as to cooperation with the Western Balkans. In line with its general pragmatism, however, prioritization has predominantly meant a narrow focus on key national interest, rather than making a strong contribution to the EU's foreign policy profile. As 
Lightfoot and Obrovsky show, important aspect of Austria's development policy - including in the EU context - reflects economic and political considerations rather than being mainly driven by (EU) development objectives. Austria's reliance on EU resources and capabilities is often subject to a similar pragmatism and is primarily used as a strategy to aid national objectives. The way Austrian diplomats interpret the value added of reports and information received by EU representations in third countries is telling here, with a diplomat stating that the value of such information should not be overstated since Austria maintains missions in those countries it is interested in (see Maurer's contribution). This again suggest that there is little enthusiasm for engaging with issues that are of concern for the EU, if they do not also coincide with key national priorities. Similarly, Lightfoot and Obrovsky point to Austria's limited involvement in shaping EU development policy, with Austria frequently acting as a 'fence sitter' whose initiatives remain limited to core Austrian concerns. Besides relying on 'prioritisation', 'strategic alliances' and cross-loading have evolved as Austrian compensation strategies for a lack of resources.

Cross-loading: To promote key national priorities - including its economic interests in Central and Eastern Europe and its interest in the stability of its neighborhood, particularly in the Western Balkans - Austria has forged durable cooperation with partner countries, as exemplified by its leading role in initiating the Salzburg Forum (Czech Republic, Hungary, Poland, Slovakia, and Slovenia) and the Central European Defense Cooperation (CEDC; Croatia, the Czech Republic, Hungary, Slovakia, and Slovenia). Providing a stable forum for routine interaction between Austria and its partner countries, these regional schemes are well suited to facilitate the 'cross-loading' of ideas, norms and ways of doing things between individual member states (Major 2005, I68; see also Wong 2005). As Müller's contribution to this special issue demonstrates, cooperation in the Salzburg Forum and CEDC has led to the emergence of a collaborative network structure, including the set-up of joint operational centres, the exchange of personal, information and experiences, and joint programmes and operational action. Austria's involvement in such collaborative projects has translated into growing horizontal exchanges and cross-border cooperation with its partners in the Salzburg Forum and CEDC. At the same time, the proliferation of multilateral schemes - which overlap in their membership and policy agendas and have established varying degrees of cooperation between them has resulted into a web of loosely connected multilateral groupings, which have the potential to also facilitate the exchange of experiences and lessons learned beyond the boundaries of individual schemes. However, as Müller also points out in his contribution, Austria's capacity for foreign policy uploading through those frameworks has also faced considerable limitations. Lacking a strong sense of collective regional identity, the Salzburg Forum and the more recent CEDC initiative largely operate on the basis of common interests. Only if the interests of its members coincide can they provide a useful means for exercising EU level influence. Here, overlapping membership with other (regional) schemes, particularly with Visegrad, can represent a real challenge in situations where Visegrad countries give preference to act through the Visegard framework rather than through the Salzburg Forum.

Both its experiences in the Salzburg Forum and in the framework of CEDC testify of Austria's challenge to collaborate with partner countries that in many respects have closer and more developed political, cultural, and historic ties with each other than with Austria. Yet, Austria's difficulty to develop durable partnership with other EU member states also has been the result of a lack of support and solidarity displayed by Austria with 'natural partners', such as its lack of support for the application process of (Central) Eastern European countries (see contributions by Kramer). Domestic politics including the events leading to sanctions of the EU-I4 in 2000, as well as political moves that catered to particular interests and widespread Eurosceptic sentiments (often supported by large media outlets) against the interests of partner countries - interfered with Austrian foreign policy and contributed to its isolation in the EU (see Kramer's contribution).

At the same time, Müller's contribution shows that particularly the growing supranationalization of the JHA domain provides a strong incentive for joint action through the Salzburg Forum, as individual countries can no longer unilaterally resist unfavourable policies at the EU level. Here, the failure to shape EU-level policy outcomes can result in high adaptation costs in the implementation phase. And in areas where its interests with its partners overlap, Austria has been able to influence policy developments on the EU level through the Salzburg Forum, including on issues such as the EU's 2010 Internal Security Strategy, the establishment of a response mechanism for exceptional circumstances met by the Schengen area in 2012, and the EU's 2015 Strategic Guidelines for JHA.

Downloading: Austria not only needed to adjust its foreign policy as a result of its membership in the EU, but also needed to respond to developments at the international and domestic level, such as globalisation, technological innovation, and increased involvement of non-state actors (see Maurer's contribution). Its pragmatic attitude towards European foreign policy also resulted in a situation where top-down Europeanization of Austrian foreign policy has often been shallow, with Austria muddling through and avoiding to address im- 
portant tensions and contradictions resulting from its involvement in the EU's foreign policy. Top-down Europeanization has been most evident with respect to structural adaptation to the EU foreign policy system (i.e. organizational structures, routines, procedures of foreign policy), which itself has evolved considerably since Austria has joined the EU. Following its entry in the EU, Austria made the necessary structural adaptations to participate in CFSP, including the establishment of European Correspondents. Moreover, to deal with CSDP issues, i.e. the defence component of CFSP, defence issues were brought into the foreign ministry (see Alecu de Flers 2012, IO2). Austrian diplomacy also needed to adapt to important procedural changes, with European foreign policy cooperation involving far reaching coordination processes that extend far beyond Brussels, including also coordination of member state embassies in third countries. The implementation of the 2009 Lisbon Treaty, which revamped the EU's foreign policy structures, again created stimuli for national adjustments. Structural adjustment has also been observed in the domain of development policy (Lightfoot/Obrovsky in this special issue). In particularly, the Austrian Development Agency (ADA) was created to make Austria fit and competitive for engaging with EU development policy.

Given the limited resources Austria invests in its foreign policy, drawing on EU structures and resources has also emerged as a strategy for cost-saving and for developing synergies (Maurer in this special issue). Among other things, Austria has displayed an open attitude towards engaging in co-location projects, sharing embassies with other member states, a form of cooperation that is supported by the European External Action Service (EEAS). Consular cooperation and integrated political crisis response arrangements have also been identified by Austria as areas as a potential tool where efficiency gains and cost savings can be realized through greater European cooperation. Here, structural adjustments to EU institutions predominantly follows a logic of achieving cost savings through EU cooperation. At the same time, the establishment of the EEAS means that a significant number of Austrian diplomats are seconded to the diplomatic service (currently 43), where they are charged with dealing with different aspects of the European foreign policy portfolio, which by far extends Austria's more narrow national agenda. Whether this involvement will also facilitate the socialization of Austrian diplomats and the evolution of a more Europeanminded diplomatic culture remains to be seen.

When it comes to Europeanization of foreign policy substance, previous research has shown that in the context of EU accession Austria has on important instances brought its foreign policy in line with the (majority) EU position, including on issues such as following a common line in terms of recognizing Slovenia and Croatia when they became independent (Alecu de Flers 2012, IO4). At the same time, after its EU accession Austria has continued to pursue national priorities, occasionally acting to the detriment of a common European approach. Most recently, Vienna's stances on the Ukraine crisis and its (energy) policy towards Russia has diverged from the markedly tough stance taken by other EU member states (de Gruyter 2014). Similarly, Lightfoot and Obrovsky show that Austria's development policy has embraced core European objectives only at the rhetoric level, while in practice Austria has made little effort to implement these objectives. Despite being subject to soft compliance mechanisms like monitoring, peer pressure and the development of best practices, Austria has made little efforts to implement EU objectives such as improving aid effectiveness or to deliver 0.7 percent of GNI as official development assistance (ODA). Overall, it appears that Austria seeks to have the best of both worlds. It embraces the rhetoric of a committed EU member state and is generally supportive of EU foreign policy integration, whilst at the same time pursues an agenda defined by narrow national interests. A similar approach of muddling through can be observes with respect to Austria's neutrality, which has been increasingly limited in scope - not least to allow for Austria's participation in CFSP and its defence component, the Common Security and Defence Policy (CSDP). For the most part, however, Austria's political elites have evaded a political debate on the status of Austria's neutrality, which enjoys widespread public support.

Domestic Politics and Europeanization: As Kramer's contribution and related works highlight, central limitations of Austrian foreign policy - and its role in the EU - are to be found in domestic politics, more than in its status as a small state. Austria has important capabilities: it has a long diplomatic history, diplomatic resources and professional staff it can draw on, is a very wealthy country that has been less impacted by the financial and economic crisis than many other economies, and it still can draw on the legacy of its active international engagement in the Cold War era, such as Vienna's role as a host of international organizations and conferences, most recently hosting high profile international talks on Iran's nuclear programme. Yet, lacking a consensual vision that could mobilize public support necessary to invest in an active foreign policy profile, subsequent Austrian governments have progressively reduced their political and financial support. Today, the level of ambition displayed by Austria's active neutrality policy very much appears as an artefact of the past, rather than serving as the 'gold standard' for Austria's contemporary foreign policy and Austria's role in the EU. For Austrian diplomats - which often excel in demanding international positions - the state of Austrian foreign policy is unsatisfying, as they increasingly lack the resources 
for substantive work. Austria refuses to invest in its role in the EU foreign policy, as it refuses to invest in its diplomatic resources, in its spending on development, as well as in its security policy (for the latter see Frank/ Braumandl-Djurdin 20I3). The reasons for this neglect are predominately to be found in domestic politics, as Austria's leading parties and political class for the most part does not seem to see it worthwhile to invest in foreign policy in a climate seemingly dominated by a Eurosceptic public and media.

\section{Outlook}

For advocates of an ambiguous Austrian foreign policy that lives up to its international responsibility, diplomatic abilities, and advanced economic status Austria's traditional resistance to foreign policy Europeanization must come as a disappointment. Participating in EU foreign policy offers opportunities to alleviate Austria's foreign policy profile and to actively contribute to shape global politics through joint European initiatives. In the Cold War era Austria has developed an active foreign policy posture, underpinned by the doctrine of its 'active neutrality' policy. This active foreign policy posture developed and reached its peak during the era of Bruno Kreisky, who served Austria as foreign minister (1959-66) and promoted an active, internationalist foreign policy as in his years as chancellor (1970-83). At that time, Austrian foreign policy had extended far beyond Europe and included the upgrading of relations with 'Third World' countries as well as involvement as a crisis mediator in key international issues at that time in areas such as the Middle East, Central America and Afghanistan. While Austria's policy of active neutrality was clearly a product of the particular international constellation prevailing at a time - marked by the Cold War division between the East and West and Austria's particular position as a neutral country between the two power blocs - it also showed that Austria had the capacity for an ambitious foreign policy that enjoyed considerable public support. Austria's active neutrality policy and its ambitious diplomacy earned it a good international reputation, with Vienna becoming to host a series of international organizations.

Yet, when Austria joined the EU in 1995 its foreign policy had already lost much of its ambition and dynamic, with Austria struggling to find its place in a substantially altered world order. Rather than conceiving its membership in the EU as an opportunity to reenergize its foreign policy through Europeanization, Austria has displayed little interest to develop an active foreign policy profile within and through the EU. Rather, Austria seems comfortable in leaving EU foreign policy initiatives to its partners, limiting its own interventions to safeguarding national interests. In many ways it appears that Austria has turned inward, priding itself with its good economic performance, low unemployment, and social policy achievements that make it stand out also among many of its European partners. Yet, what appears like a highly pragmatic or 'economical' approach to international relations - which places much of the initiative, responsibility, and burden on Austria's partners in the EU - does not necessarily serve Austria's international reputation.

Against the backdrop of mounting foreign policy challenges faced by the EU today, Austria's low profile role must increasingly appear as a lack of solidarity and decisiveness. Still struggling with the effects of the 2008 financial crises the EU not only faces central internal challenges, but it is also confronted with major foreign policy challenges. Instability and violent conflict in the EU's neighbourhood, which is at the core of the current refugee crisis faced by the EU, requires a collective European response. The example of Sweden - which has developed an ambitious foreign policy, even earning itself the reputation of a 'humanitarian superpower' shows that small to medium sized member states can play a prominent role in EU foreign policy. By contrast, Austrian foreign policy lacks a strong vision and sense of purpose that could mobilize a more ambitious, proactive foreign policy. Again, it appears that the principle limitation for Austria is not its character as a small state in the EU, but the lack of an ambitious vision that could trigger a real investment in foreign policy.

\section{Literature}

Alecu de Flers, Nicole/Patrick Müller (2010). Applying the Concept of Europeanization to the Study of Foreign Policy: Dimensions and Mechanisms. Paper prepared for the GARNET Conference 2010 in Brussels. Internet: http://www.ies.be/files/M\%C3\%BCller-B3. pdf (accessed: 4.2.2016).

Alecu de Flers, Nicole (20I2). EU Foreign Policy and the Europeanization of Neutral States: Comparing Irish and Austrian Foreign Policy, London/New York.

De Gruyter, Caroline (2014). Austrian Acrobatics in Europe, Carnegie Europe, 5 November 20I4. Internet: http://carnegieeurope.eu/2OI//I/o5/austrianacrobatics-in-europe (accessed: 4.2.2016).

Fearon, James (1998). Bargaining, Enforcement, and International Cooperation, in: International Organization, Vol. 52(2), 269-30I.

Frank, Johann/Wolfgang Braumandl-Djurdin (Hg.) (2OI3). Parameter europäischer Sicherheit: Die GSVP zwischen Strategischer Herausforderung und Nationalstaatlicher Räson, Vienna. 
Gärnter, Heinz (2006). Österreichische Außen- und Sicherheitspolitik, Working Paper Austrian Institute for International Affairs (OIIP), Vienna.

Hagan, Joe D. (1993.) Political Opposition and Foreign Policy in Comparative Perspective, Boulder.

Holzinger, Katharina/Frank Schimmelfennig (2012). Differentiated integration in the European Union: many concepts, sparse theory, few data, in: Journal of European Public Policy, Vol. I9(2), 292-305.

Kramer, Helmut (2013). Österreichs Beitrag zur europäischen und globalen Sicherheit. Ein Plädoyer für mehr Selbstbewusstsein im Bekenntnis zu aktiver Neutralitäts- und Friedenspolitik., in: Thomas Roithner/Johann Frank/Eva Huber (eds.), Wieviel Sicherheit braucht der Friede? Zivile und militärische Näherungen zur österreichischen Sicherheitsstrategie. Vienna, 89-Ioo.

Major, Claudia (2005). Europeanisation and Foreign and Security Policy - Undermining or Rescuing the Nation State?, in: Politics, Vol. 25(3), 175-190.

Miller, Aaron D. (2013). Are Domestic Politics Evil ? What really happens when the national interest meets the water's Edge, Foreign Policy online contribution July 2013. Internet: http://foreignpolicy.com/2013/o7/o2/ are-domestic-politics-evil/_(accessed: 4.2.2016).

Moravcsik, Andrew (1997). Taking Preferences Seriously: A Liberal Theory of International Politics, in: International Organization, Vol. 5I(4), 513-553.

Müller, Patrick (2012). EU Foreign Policymaking toward the Middle East Conflict - the Europeanization of National Foreign Policy, New York.

Müller, Patrick (2016). EU Foreign Policy: No Major Breakthrough Despite Multiple Crises, Journal of European Integration, Vol. 38(3), 39-74.

Normann, Christine (2012). Analysing the Evolution of the European Neighbourhood Policy: Theoretical and Methodological Triangulation. In: Edmund Ratka/Olga Spaiser (eds.): Understanding European Neighbourhood Policies. Concepts, Actors, Perceptions, Baden-Baden, 53-68.

Palosaari, Teemu (201I). The Art of Adaption. A study on the Europeanization of Finland's foreign and security policy. TAPRI Studies in Peace and Conflict Research No. 96. Internet: https://tampub. uta.fi/bitstream/handle/IOO24/97987/the_art of_adaptation_20II.pdf? sequence $=\mathrm{I}$ (accessed: 4.2.2016).

Panke, Diana (2010). Good Instructions in No Time? Domestic Coordination of EU Policies in I9 Small States, in: West European Politics, Vol. 33(4), 770790.

Pucher, Johann/Johann Frank (Hgs.) (2012). Strategie und Sicherheit 2012. Der Gestaltungsspielraum der österreichischen Sicherheitspolitik, Vienna.
Putnam, Robert D. (1988). Diplomacy and Domestic Politics: The Logic of Two-Level Games, in: International Organization, Vol. 42(3), 427-460.

Rose, Richard/Alexander Trechsel (2013). How Size Matters: Portugal as an EU Member, Studies in Public Policy, No. 500, Glasgow.

Wong, Reuben (2005). The Europeanisation of Foreign Policy. In: Christopher Hill/Michael Smith (eds.), International Relations and the European Union. Oxford, 134-153.

Smith, Alstair (1996). Diversionary Foreign Policy in Democratic Systems, in: International Studies Quarterly, Vol. 4O(I), I33-I53.

Tonra, Ben (2015). Europeanization, in: Knud Erik Jorgensen/Aasne Kalland Aarstad/Edith Drieskens/ Kathie Laatikainen/Ben Tonra (eds.), SAGE Handbook of European Foreign Policy, London, I83-196.

Smith, Michael E. (2004). Institutionalisation, Policy Adaptation and European Foreign Policy Cooperation, in: European Journal of International Relations, Vol. 10(1), 95-136.

\section{Authors}

Dr. Patrick Müller is Ikerbasque Research Fellow at the Faculty for Social Science at the University of the Basque Country. From 2009 till 2015 he was Assistant Professor at the Institute for European Integration Research at Vienna University. Patrick was also working as Transatlantic Post-doc Fellow for International Relations at the German Institute for International and Security Affairs (SWP), the Institut Français des Relations Internationales (IFRI), Paris, and at the Johns Hopkins University in Washington DC. His research interests include Theories of International Relations, EU Foreign Policy, the role of the EU in global governance, European Policy toward the Middle East and the Mediterranean, and the Middle East conflict.

Dr. Heidi Maurer is Assistant Professor in European Union Foreign Policy Making at the Faculty of Arts and Social Sciences at Maastricht University. In 2012/13 she was the Austrian Marshall Plan Foundation Fellow at the Centre for Transatlantic Relations (CTR) at the School for Advanced International Studies (SAIS) at Johns Hopkins University in Washington DC. Heidi's research interest focus on EU foreign policy-making, European diplomacy, and the European Neighbourhood Policy. Since joining Maastricht University, Heidi also engages actively in research about alternative teaching methods and in particular Problem-Based Learning. 
